\title{
Breaking Moulds, Smashing Mirrors: The Intertextual Dynamics of D. H. Lawrence's "The Lovely Lady"
}

\author{
Conchita Díez-Medrano \\ Universidad Autónoma de Madrid
}

\begin{abstract}
D. H. Lawrence's aversion against Platonic idealism evidences itself in his repeated attempts to debunk in his fictions the way in which women disown their own bodies by unconsciously moulding themselves according to "men's theories of women." One of such fictions would be "The Lovely Lady," a story which characteristically engages in a silent dialogue with traditional discourses about women. In so doing, it cogently exposes the male glance that inhabits the mirror in which the woman protagonist sees herself reflected and, concurrently, subvert the traditional binary paradigm witch/angel in which she has been kept a prisoner all her life.
\end{abstract}

A dead intuitive body stands there and gazes at the corpse of beauty . . Modern people ... stand in front of a Botticelli Venus, which they know as conventionally "beautiful" ... they are still dominated by that unnamed, yet overmastering dread and hate of ... the strange intuitional awareness of the body.

D. H. Lawrence, "Introduction to these Paintings"

D. H. Lawrence's lifetime struggle was, as the quotation above evidences, the same as some of his own contemporaries'; namely, a struggle to liberate the body from the stifling constrains of Platonic idealism. Closely related to this issue is Lawrence's deep concern with the way in which the twin discourses of art and literature had effectively contributed to taming the female body, and how such discourses had in turn been internalized by women. Whether in discursive or dramatic form, he would never tire of bringing to light 
how women disown their own bodies by unconsciously moulding themselves according to "men's theories of women" ("Give Her a Pattern" 393).

Lawrence, however, would go further than many of his contemporaries in his various attempts to shatter in his fictions the mirror in which, as he himself believed, women saw themselves reflected. This can already be appreciated in Sons and Lovers. Indeed, one recalls that memorable scene in which Mrs Morel, pressed by her own grown up children to look after her physical appearance, turns herself into a "sight"; and the subtle irony that arises from the juxtaposition of Mrs Morel's sarcasm about her own looks with the seriousness that pervades Paul's perlocutionary remark: “Then she sniffed into her sarcastic manner, and was sure she looked a sight. But she looked a lady, Paul declared, as much as Mrs Major Moreton, and far, far nicer" (298; my emphasis). Sons and Lovers, however, is only one in a long series of fictions in which the pressure that the male beauty game exerts upon women is overtly denounced. Other such fictions would include "The Shades of Spring” (1914), “The Thimble” (1915), The Ladybird (1921), and last but not least, "The Lovely Lady" (1927), which is the story I want to examine in this paper.

Compared with the other stories mentioned above, "The Lovely Lady" has attracted very scant attention. Then, those very few critics who have approached the story have frequently been biased by some of Lawrence's extra-fictional statements on the subject of motherhood. Often unwilling to see beyond Lawrence's presumed "motherphobia" and "Oedipus complex," these critics have importantly failed to appreciate the story's intertextual dynamics, i.e., its parodic force (e.g., Sheila MacLeod, 175; Laurence Lerner, 70). ${ }^{1}$ In so doing, they have been led to perpetuate the myth that Lawrence mothers are devouring "Moms" worthy of contempt.

In the light of such critical lapses I propose, first of all, to explore the way in which the narration itself manipulates our sympathies vis-à-vis each of the characters involved. This will in turn lead us into a close examination of what actually lies behind the mother/son relationship, namely, what I believe is a cogent criticism of an entire malecentered cultural tradition that confines women to the traditional paradigm angel/witch. Following this, we shall be in a better position to assess, in the final section of this paper, the rather subversive import of the story's denouement.

It can hardly be denied that an all-too-familiar mother-blaming discourse seems to permeate the story. Yet, as with many other Lawrence fictions, one needs to be particularly attentive to the source from which such a discourse emanates and the way in which the narrative taken as a whole endorses it before drawing any definite conclusion. With regard to "The Lovely Lady," one cannot fail to appreciate that, just as Mrs Morel's "overmotherliness" in relation to Paul in Sons and Lovers is principally communicated through Miriam; and just as the idea of Mrs Durant's crippling effect upon Alfred in "Daughters of the Vicar" is conveyed by Louisa; so is the mother-blaming discourse that riddles "The Lovely Lady" mainly woven in by Cecilia: ${ }^{2}$ 
[Robert] was, and Ciss knew it, more confused than shy. . . In the lovely lady's womb he must have felt very confused. (bold-faced characters added, 764)

Poor Robert was by nature a passionate man. His silence and his agonised, though hidden, shyness were both the result of a secret physical passionateness. And how Pauline could play on this! Ah, Ciss was not blind to the eyes which he fixed on his mother-eyes fascinated yet humiliated, full of shame. He was ashamed that he was not a man. (765)

But what a devil of a woman! She even knew that she, Cecilia, had mentally accused her of killing her son Henry ... And lately she had been thinking that Pauline was going to kill Robert as she had killed Henry. It was clear murder: a mother murdering her sensitive sons, who were fascinated by her: the Circe! (768)

This is Pauline, a "mother-monster" and "castrating figure," as seen through the eyes of Cecilia. Furthermore, it is a description one is, for the time being, enticed into taking as trustworthy. Indeed, in as much as it issues from Cecilia, that is, a character whom we are led to sympathize with for two reasons: firstly, because we are constrained to her own stance exclusively, and secondly, because the narration creates an identity nexus between us and Cecilia by granting us a privilege which only she enjoys, namely, that of observing Pauline as she sits in her dressing-room and, consequently, by making us secret sharers of Cecilia's secret knowledge: "[Pauline's] niece Cecilia was perhaps the only person in the world who was aware of the invisible little wire which connected Pauline's eye-wrinkles with Pauline's willpower" (481).

In contrast with Sons and Lovers where, one recalls, Miriam's opinion of Paul's mother is amply and convincingly contradicted by Mrs Morel's self-representation, Pauline's unmediated characterization appears to strengthen Cecilia's negative judgement of her: "Only with her niece Cecilia she did not trouble to keep up the glamour. Ciss was not very observant, anyhow; and more than that, she was plain" (482). Pauline's reflection at this point does not so much bring discredit on Cecilia as it promotes our negative view of her; the implication is that only those who partake in her niece's lack of acuteness are allowed to see (as we ourselves are) her true self. Perhaps more crucial is the fact that this brief insight into Pauline's mind confirms in advance the accuracy of Cecilia's later diagnosis of Robert's poignant anxiety, one which from her point of view is contingent upon Pauline's maternal over-possessiveness.

Significantly, the next time one is permitted to see into Pauline's mind, Cecilia's version of the latter is further consolidated:

"I am disappointed in you, Robert. There is no poignancy in you. Your father was a Jesuit, but he was the most perfect and poignant lover in the world. You are a Jesuit like a fish in a tank." (774)

This self-confession underscores Pauline's egoistic projection of her own unfulfilled desires onto Robert. Unsurprisingly, some critics (e.g., Michael Squires 51; Sheila MacLeod 174) have been led to conclude that in this particular story Lawrence underwrites 
a whole literary tradition which condemns "assertive females" for "[emptying] of their manliness" the men (sons or lovers) to whom they relate (Michael Squires 51). It is unquestionable that this extract smacks of Lawrence ideas about maternal love such as he expressed them in Fantasia of the Unconscious:

The unhappy woman beats about for her insatiable satisfaction, seeking whom she may devour. And usually, she turns to her child. . . He is a medium to her ... so she throws herself into ... a final and fatal devotion, that which would have been the richness and strength of her husband and is poison to the boy. (125)

However striking these parallelisms may be, one should beware of superimposing this nonfictional grid upon "The Lovely Lady," lest one misses one of the most significant characteristics of Lawrence fictions: the way in which they continually obstruct any stable sympathy towards any of his characters.

Indeed, returning to "The Lovely Lady" one notices how, after having been manipulated into sharing Cecilia's hostile stance towards Pauline, the narration suddenly changes gear in mid course and forces us into taking our distance from Cecilia by progressively revealing the real motivation that underlies her opposition to Pauline:

Oh, especially in Italian Cecilia heard the poisonous charm of the voice, so caressive, so soft and flexible, yet so utterly egoistic. She hated it with intensity as it sighed and whispered out of nowhere. Why, why should it be so delicate, so subtle and flexible and beautifully controlled, when she herself was so clumsy? Oh, poor Cecilia, she writhed in the afternoon sun, knowing her own clownish clumsiness and lack of suavity, in comparison. (774; my emphasis)

Therefore, and in a way strikingly reminiscent of Virginia in Lawrence's "Mother and Daughter," Cecilia's hatred of her aunt is not so much motivated by jealousy; rather, jealousy is only a facade covering Cecilia's idealization of Pauline as an enviable paragon of perfection, or the person she herself would like to be. In fact, long before this climactic insight, Cecilia's desire to be like Pauline has already been hinted at on two other occasions. One recalls, for example, the way in which she decides to sunbathe in imitation of Pauline: "One afternoon it occurred to Cecilia that she herself might while away this rather long afternoon by taking a sun-bath" (766; my emphasis). The banality of Cecilia's "occurrence" dissipates when the meaning of the performance she is in fact imitating is disclosed: "'Enough sun, enough love-thrill, enough proper food, and not too much of them, and a woman might live for ever" ( 768 ; my emphasis). Pauline's explication of her sun-bathing ritual retroactively qualifies Cecilia's decision as the beginning of her own self-obliteration. The key issue here is that, in so duplicating her aunt's artful performance, Cecilia's critical stance towards Pauline's cosmetic game turns now against herself, thus rendering her as censurable a figure as Pauline. What is more, she becomes the main butt as one reaches the climactic drain-pipe episode:

Oh, it was awful. The sun shone, the sky was blue, all seemed so lovely and afternoony and summery. And yet, oh, horror!-she was going to be forced to believe 
in the supernatural! And she loathed the supernatural, ghosts and voices and rappings and all the rest. (767)

As one critic has remarked, one recognizes at this particular point, and throughout the whole drain-pipe scene, a parody of traditional tales of the uncanny such as these are epitomized by Poe's (Harris 228). This question will be considered later. For present purposes, and with a view to understanding the import of the denouement, what needs to be emphasized now is that in the extract quoted the narration undermines Cecilia, and forces our own critical detachment from her immediately before the resolution begins to unfold.

Just as the narration obstructs our unqualified sympathy towards Cecilia, so does it preclude any possible perception of Robert as the defenceless victim he appears to be in the eyes of his cousin. While the narration drives us to detach ourselves from Pauline by foregrounding her intense egotism vis-à-vis her son, it likewise forecloses any commiseration with Robert by negatively exposing his deliberate procrastination of action, which is his failure to assume responsibility for his own life:

Perhaps Ciss was the only person who fathomed his awful shyness and malaise, his habitual feeling that he was in the wrong place: almost like a soul that has got into a wrong body. But he never did anything about it. (763; bold-faced characters mine)

The narrator plays down Pauline's liability by intimating Robert's contribution to the existing state of affairs; that is, by making it explicit that Robert can actually take action in order to reverse the situation in which he is enmeshed. Somebody might want to argue that Robert, being so deeply dominated by his mother, is blinded to this possibility. To argue so, though, would importantly overlook a dialogue in which Robert is shown to be consciously aware of the factual possibility of taking his life in his own hands, of escaping his mother's "thralldom":

"My life, certainly, is a negative affair."

[Cecilia] hesitated before she dared ask him:

"And do you mind?"

He did not answer her at all. Her heart sank.

"You see, I am afraid my life is as negative as yours is," she said. "And I'm beginning to mind bitterly. I'm thirty."

She saw his creamy, well-bred hand tremble.

"I suppose," he said, without looking at her, "one will rebel when it is too late." (771; emphasis added)

This dialogue lays bare Robert's consciously delayed "rebellion," to the effect of preventing our feeling any commiseration towards him. This is further reinforced when we are made to apprehend the real reason behind Robert's postponement, namely, the comfortable position which his dependency on Pauline affords him: 
[Robert] was a barrister, and, to his secret but very deep mortification, he earned about a hundred pounds a year. He simply couldn't get above that figure, though it was rather easy to get below it. Of course, it didn't matter. Pauline had money. But then, what was Pauline's was Pauline's, and though she could give almost lavishly, still, one was always aware of having a lovely and undeserved present made to one: presents are so much nicer when they're undeserved, Aunt Pauline would say. (762)

Once again, this instance of free indirect style reveals not so much Pauline's inescapable economic subjection of Robert, but the latter's self-enslavement rooted in material expediency. Contrast this excerpt with Robert's instance of direct speech: "And how can I marry?' he said. 'I am a failure even at making money. I can't ask my mother for money" ; Cecilia's reply is no less revealing: "Then don't bother yet about marrying,'she said. 'Only love me a little. Won't you?"” (773).

Thus "The Lovely Lady" cannot be simplistically summarized as a case of matriphobia. Indeed, the more one fathoms the story, the more the blame appears to be displaced towards the son as the actual representative of a highly pernicious discourse.

\section{II}

Earlier I alluded to Pauline's projection of her own unfulfilled desires upon Robert. Yet there is another side to her self-projection on her son:

[Mother and son] deciphered manuscripts and discussed points, Pauline with that eagemess of a girl, for which she was famous ... Robert, solid, rather quiet and subdued, seemed like the elder of the two: almost like a priest with a young girl pupil. And that was rather how he felt. (764)

Here we are driven into seeing this pair not as mother and son but as a daughter (pupil) and a father (teacher-priest). We are seemingly enticed, that is, into perceiving Pauline as vicariously re-living her own relationship with her dead father through her son; a female experience which, one may say in passing, recurs in yet another Lawrence story, "The Princess," where the female protagonist Dolly Urquhart can be similarly seen to re-live her childhood days with her father through the figure of Romero. Returning to Pauline, one notices her self-dedication to the collection she has inherited from her father:

Her father had been ... a devoted collector of beautiful exotic things. When he died ... he left his collection of treasures to his daughter. And Pauline, who had really a passion and a genius for loveliness . . had laid the basis of her fortune on her father's collection. She had gone on collecting, buying where she could, and selling to collectors or to museums. (769)

As one critic has shrewdly remarked, Pauline's devotion to augmenting her father's art collection, the fatherly intellectual bond that unites her to Robert, and her compulsive concern with her personal looks -as if attempting to turn herself into a work of art- 
converge to suggest that Pauline is dominated by a dead father with whom she would be striving to fuse and to whom she would be offering herself as one more work of art for his collection through her own son Robert. ${ }^{3}$ Once one realizes that Pauline's attachment to Robert is in fact a devotion to a father surrogate, "The Lovely Lady" acquires an altogether new dimension.

In relation to the foregoing remark this study contends that "The Lovely Lady" is a subtly conducted denunciation of "the lesson of the Master," that is, of the "lesson" which teaches women to obliterate themselves behind a mask of beauty for the pleasure of a male spectatorship. As noted in the introduction, the exposure of the male gaze as chief originator of the double bind of the beauty game in which women like Pauline and Cecilia appear to be enmeshed already permeates earlier Lawrence works. For example, it is already intimated in Sons and Lovers, where Mrs Morel, pressed by her own grown up children to look after her physical appearance, turns herself into a "sight"; one recalls the subtle irony that arises from the juxtaposition of Mrs Morel's sarcasm about her own looks with the seriousness that pervades Paul's perlocutionary remark: "Then she sniffed into her sarcastic manner, and was sure she looked a sight. But she looked a lady, Paul declared, as much as Mrs Major Moreton, and far, far nicer" (298).

Likewise, the pressure that the beauty game exerts upon women is overtly foregrounded in "The Thimble" (1915), a story which, were it not for the fact that it was composed some twelve years earlier, could have been taken for the second part of "The Lovely Lady"; indeed, for here is a woman who, although in love with Mr Hepburn, hesitates about marrying him because, like Robert, he is a barrister earning little money. Only when he joins the army will she agree to marry him:

"If you want to love your husband," she said to her friends ... 'you should see him in khaki.' And she had really loved him, he was so handsome in uniform. (190) ${ }^{4}$

The heroine's concern with external appearances in "The Thimble" is not harshly satirized; on the contrary, as the tale advances, the narration denaturalizes her preoccupation with beauty by bluntly presenting it as a painful burden which society has imposed on her:

She knew she was a beauty, she knew it was expected of her that she should create an impression of modern beauty. And it pleased her, it made her soul rather hard and proud; but also, at the bottom, it bored her. (192)

When Lawrence re-wrote the tale in 1921 as The Ladybird the theme of female cosmetic beauty became more central. In the novella version one can even regard Lady Daphne as the precursor of Pauline Attenborough, especially when one sees her admiring in the mirror "her wonderfully cared-for face, that had appeared in so many society magazines" while at the same time wondering about what would really happen if her "lovely bluegreen iris drawn tight like a screen ... should relax ... unfold, and open out the dark depths, the dark, dilated pupil" (182), that is, as Pauline's eyes do in the privacy of her room. But again, even though cosmetic beauty is criticized, the actual target of satire 
in this story is her husband Basil, the ultimate idealizer of woman, or the glance motivating Daphne's self-burial within a "white sepulchre" (182).

Nowhere is the denunciation of the male gaze as epitomized by Basil (and Robert, as will be seen shortly) more categorical than in "The Shades of Spring" (1914). ${ }^{5}$ Even though this tale is not directly concerned with the game of beauty, it exposes its foundations: the male reification of women into artful objects. In this story, the actual exposure falls to the male protagonist who, confronting his first love (Hilda), accuses himself of having "taken her for something she was not":

that was his fault, not hers.

He was startled to see his young love, his nun, his Botticelli angel, so revealed .. . She only wanted to keep up a correspondence with him- and he, of course, wanted it kept up, so that he could write to her, like Dante to some Beatrice who had never existed save in the man's own brain. $(108 ; 110$; my emphasis)

The link which Syson establishes between his idealization of Hilda on the one hand, and women in Art (painting, literature) on the other is precisely what lies at the heart of "The Lovely Lady." In effect, looking attentively into the first narratorial descriptions of Pauline it soon becomes apparent that here is something more than a literally ageless mother:

Mrs Attenborough's face was of the perfect oval, and slightly flat type that wears best. . . . Her nose rode serenely, in its finely-bridged curve. Only the big grey eyes were a tiny bit prominent on the surface of her face ... The bluish lids were heavy, as if they ached sometimes with the strain of keeping the eyes beneath them arch and bright; and at the corners of the eyes were fine little wrinkles which would slacken with haggardness, then be pulled up tense again, to that bright, gay look like a Leonardo woman who really could laugh outright. ... .

She really had the secret of everlasting youth; that is to say, she could don her youth again like an eagle. . . . Her son Robert, in the evenings, and Sir Wilfred Knipe sometimes in the afternoon to tea: then occasional visitors on Sunday, when Robert was home: for these she was her lovely and changeless self, that age could not wither, nor custom stale: so bright and kindly and yet subtly mocking, like Mona Lisa, who knew a thing or two. (761; emphasis added)

Pauline's resemblance to the lady of Poe's "The Oval Portrait" is striking. ${ }^{6}$ One recalls that Poe's tale is about a "maiden of rarest beauty, and not more lovely than full of glee," who "[hated] only Art which was her rival," and who perished for it in the end (291). But there are more Poesque resonances in this narratorial portrayal of Pauline, for one further perceives remarkable similarities between her and Poe's Ligeia, whose "beauty of face no maiden ever equalled" and "whose loveliness was indeed 'exquisite" despite some indefinite "irregularity" on her face ("Ligeia" 655).

Interestingly, just as Pauline is covertly associated with a typically Poesque angelic heroine, she is also connected with both Leonardo da Vinci's Mona Lisa and Walter 
Pater's reconstruction of the latter. Once again, Aquien strikes a chord here, for he very perceptibly calls attention to the parallelisms between Pauline and the "[monstrous]" Mona Lisa which Pater describes in his chapter dedicated to Leonardo da Vinci in The Renaissance (76). ${ }^{7}$ Added to Pauline's resemblance to Pater's Mona Lisa there is her equally implicit affinity with Shakespeare's Cleopatra, invoked in the phrase "that age could not wither, nor custom stale" (II. ii). Finally, Pauline is the lady of an Impressionist painting, the fleeting impression of a lady, an effect carefully achieved through a combination of light and colour:

[By] candlelight she looked, yes, a Spanish high-bred beauty of thirty-two or three. She set the candles to give her face just the chiaroscuro she knew suited her; her high chair that rose behind her face was done in old green brocade, against which her face emerged like a Christmas rose. (483; emphasis added)

All these parallelisms would patently indicate that Pauline does not merely encapsulate the traditional angel/witch of patriarchal ideology; more importantly, she embodies a whole tradition of polarized portrayals of women in literature and the visual arts from the Renaissance (Shakespeare/Leonardo da Vinci) to the nineteenth century (Poe, Pater/the Impressionists). One could conjecture that what is actually being ironized is not Pauline as such, but the very tradition she encapsulates, that is, an "infinite variety" of invariable women; or, as Aquien has suggested, that Lawrence's "The Lovely Lady" is fundamentally concerned with the "dénonciation brutale de l'artifice," in ways comparable to Oscar Wilde's The Picture of Dorian Gray (71). Yet, in contrast with Wilde's, the exposure of the artifice in Lawrence's tale is not an end in itself, but a means leading straight into the critical exposure of the artificer, which is nothing but the tradition at issue, and without which the artifice could not possibly have been brought into existence.

Unquestionably, Lawrence's story entertains a silent dialogue with Wilde's- thus augmenting the intertextual force which permeates "The Lovely Lady." It is not, however, a repeat of The Picture of Dorian Gray; rather, it is a revisionist re-writing of it insofar as it centralizes what Wilde pushes to the margins of the novel: Sybil's episodic tragedy, or the tragedy of a woman who "would not follow the [beauty] game" and hence "[exposed] herself for what she [was]-not the fair sex" (Stannard 192). This in turn connects with what is the fundamental difference between the works. One recalls that in The Picture of Dorian Gray we are made to watch the portrait change in the course of the novel while Dorian himself remains untransformed until the very end when his whole body suddenly disintegrates. In contrast, Pauline and "the lovely lady" are inextricably woven together all the way through.

This may seem banal, unless we realize that this is precisely the reason why, from our vantage point as readers, Pauline does not change when Cecilia "suddenly [switches] on the strong light by the door" (775). What we are made to see now is the same "made-up," 
"haggard" old woman of the opening pages, with exactly the same "haggard and old and tired" eyes (761); indeed, the same old "coquettish" woman putting up the same youthful performance in front of her son ("[she] held her daintly-slippered foot to the fire," and "[her] body tried to repeat all the old graceful gestures" [777]). In truth, the effect of Cecilia's action is not the destruction of the artifice but the smashing of the mirror, or Robert's refractory glance:

\footnotetext{
"Why, mother, you're a little old lady!" came the astounded voice of Robert: like an astonished boy: as if it were a joke.

"Have you only just found it out?" snapped the old woman venomously.

"Yes! Why, I thought-" his voice tailed out in misgiving. (776)
}

Through Robert's expletive the narration powerfully elucidates that "the lovely lady" is in fact the artistic creation of Robert, the glance that inhabits the "mirrors" which Pauline asks to have "taken away from her room" at the end of the narrative (778). What this final gesture would seemingly indicate is that, had there been no male glance (Robert's) inhabiting these mirrors in the first place, there would never have been any "lovely lady." In the last instance, in so smashing the mirror "The Lovely Lady" indirectly debunks all those artistic images it has previously encoded; artistic images of women which from Shakespeare's to Wilde's have continually imprisoned women within the binary paradigm of Witch-(Pauline)/Angel-(the lovely lady), and thus denied women's essential fluidity, that is, their mortal selves, their own bodies. ${ }^{8}$

It is rather significant that just as "The Lovely Lady" lays bare what lies behind the beauty game, it also opens a breach through which one may apprehend how "women almost inevitably turn against women because the voice of the looking glass sets them against each other" (Gilbert and Gubar 40; emphasis added). As "The Lovely Lady" progresses, the narration opens a critical chasm through which Cecilia's hostile attitude towards Pauline can be seen to be rooted in an intense desire to be (like) Pauline. Having so distanced us from Cecilia by turning her into a butt, the narration concomitantly enables us to take heed of the dramatic irony in which Cecilia appears to be enmeshed. For while she courageously brings herself to terminate Pauline's counterfeit (the beauty game), she unconsciously sets the machinery back into motion by stepping inside the frame from which she has just pushed Pauline:

Cecilia went down the covered passage to her own house, and dressed carefully for dinner, putting some white columbines at her breast.

The drawing-room was lit with a softly-shaded lamp. Robert ... was waiting . . Cecilia came in with the white flowers nodding at her dusky breast. Robert was watching her curiously, a new look on his face. (775; emphasis added)

It could be argued that the narration at this point ironically represents the beauty/youth game as unbreakable. Alternatively, this passage could be seen to cast a mocking glance upon Cecilia's active collaboration in the patriarchal game which the narration, taken as 
a whole, powerfully disparages. Actually, when considered in the light of Pauline's death, this alternative is not as unlikely as it might first appear.

At first sight, Pauline's suicide would apparently contradict what I suggested earlier: that "The Lovely Lady" is a revisionist re-writing of Wilde's. In effect, the similarity of the heroines' deaths is remarkable:

And two days later, Pauline was found dead in her bed, having taken too much veronal, for her heart was weakened. (778; emphasis added)

They ultimately found [Sybil] lying dead on the floor of her dressing-room. She had swallowed something by mistake, some dreadful thing they used at theatres. I don't know what it was, but it had either prussic acid or white lead in it. (The Picture 72)

Taking Pauline's death together with Cecilia's imitative behaviour of Pauline one would be inclined to surmise that, after all, the story is perpetuating male-centered ideology. Yet to conclude so would severely overlook the import of Pauline's last stroke:

From the grave even she hit back at her son and her niece. She left Robert the noble sum of one thousand pounds; and Ciss one hundred. All the rest, with the nucleus of her valuable antiques, went to form the "Pauline Attenborough Museum." (778)

The implications that lie behind this apparently jocular closing paragraph are significant; in so creating her own museum, Pauline ceases to be a cultural artifact in order to become an active participant in Culture. In so promoting a woman to the rank of cultural precursor, the narration may even be taken to pour its mirth upon the male-centered culture in which Pauline, until then, has been imprisoned. Furthermore, it would also intimate that Pauline's active participation in Culture can only come into effect with the repossession of her body, a repossession which Cecilia unknowingly facilitates by breaking the mirror in which she has remained incarcerated until then. Needless to say, this is quite a revisionist reversal of the traditional paradigm (Female-Body-Nature/Male-Mind-Culture), for what Lawrence's narrative actually does is to blur its terms by rewriting instead one single propositionFemale (Body) Culture.

\section{Notes}

1. Judith Arcana extends this criticism to prevailing assessments of Sons and Lovers; the author of the present essay fully agrees with her view that Sons and Lovers, as much as other fictional representations of mothers in Lawrence's fiction, has been misleadingly examined through "the Freudian Oedipal hypothesis," a tendency which she finds "embedded in the sociocultural phenomenon of mother-blaming" and which "[encourages] each of us to condemn mothers for thwarting us, repressing us, raising us for selfish purposes, refusing to let us go, even dominating our emotional lives after their deaths" (I Remember Mama" 137-8). 
2. In all three stories the narration represents the sons' felt bitterness about their dependency on their mothers, whom they in turn blame for their own incapacity to love any other woman. Yet at the level of self-representation, that is, outside the discourse of their respective sons or suitors, neither Mrs Morel in Sons and Lovers nor Mrs Durant in "Daughters of the Vicar" can be seen to fit into the frame in which the latter have put them.

3. As Aquien puts it, "Tout se passe comme si Pauline, devenue oeuvre à son tour, cherchait à s'offrir fantasmatiquement à un père qu'elle tenterait de valoriser par sa passion pour un héritage dont Lawrence [sic] dit qu'elle faisait tout pour l'enrichir et l'améliorer."

4. Originally written in 1915, it took Lawrence two years to get "The Thimble" published in Seven Arts; he completely re-wrote it in 1921 as The Ladybird, which was then published together with The Captain's Doll and The Fox.

5. This story was composed in 1911 and published two years later by Forum; Lawrence substantially modified it in 1914 for its inclusion in The Prussian Officer.

6. Some of the intertextual parallels I shall be referring to hereafter have been noted by Aquien; unfortunately, he chooses to concentrate on the psychoanalytical implications of the tale to the effect of failing to put the tale's inherent dialogism into perspective.

7. "Si Lawrence associe Pauline à Mona Lisa 'who knew a thing or two' sans rien ajouter sur l'objet de sa connaissance, Pater, avant lui, attribua à la Joconde un savoir mystérieux, tout entier marqué d'inquiétante étrangeté. Si Pauline et la Joconde ont le même regard ['The bluish lids were heavy' (The Lovely Lady); 'The bluish lids were heavy' (The Renaissance)] c'est que toutes deux partagent le même souci: connaître l'éternité, 'the secret of everlasting youth' pour Pauline, '[the] fancy of a perpetual life' pour la Mona Lisa de Pater" (Aquien 76).

8. Unna Stannard locates the beginning of women's "exclusive identification" in the Italian Renaissance, particularly in Raphael's sculpture and paintings where "the female nude began to predominate"; this identification would then have become a "fait accompli" "around the 1830s," when "men gave up wearing bright colors, silks, laces, earrings, and perfumes and stopped setting their hair. Men no longer showed off their legs; instead they wore trousers ... they now conceal everything and signify their maleness by a symbol-the necktie" (191). Compare with Lawrence's "Introduction To These Paintings," where he severely criticizes a tradition which, beginning with Shakespeare, Dante and Botticelli, and ending with the Impressionists, has continually recoiled, like Shakespeare's Hamlet, from the horror of sex, thus covering it up with "ideal beings, creatures that exist in idea, to one another, rather than flesh-and-blood kin" (556).

\section{Works cited}

Aquien, Paul. "Le visage et la voix dans 'The Lovely Lady." Etudes lawrenciennes $\mathrm{n}^{\circledR} 2$ (1988). 71-80

Arcana, Judith. "I Remember Mama: Mother-Blaming in Sons and Lovers Criticism." The D. H. Lawrence Review 21 (1989): 137-65.

Gilbert, Sandra M. and Susan Gubar. The Madwoman in the Attic: The Woman Writer and the Nineteenth-Century Literary Imagination. New Haven, Conn., and London: Yale University Press, 1979.

Harris, Janice H. The Short Fiction of D. H. Lawrence New Brunswick, NJ: Rutgers University Press, 1984. 
Lawrence, D. H. "The Lovely Lady," 1927. Comp. in The Complete Short Stories of D. H. Lawrence. Vol. 3. London: Heinemann, 1955. 3 Vols. 761-78.

--. "Introduction To These Paintings," 1929. Comp. in Phoenix: The Posthumous Papers of $D$. H. Lawrence. London: Heinemann, 1936. 551-84.

--.. "The Shades of Spring," 1914. Comp. in The Prussian Officer and Other Stories. Ed. John Worthen. Cambridge: CUP, 1983. 98-113.

---. "The Thimble," 1917. Comp. in England, My England and Other Stories. Ed. Bruce Steele. Cambridge: CUP, 1990. 190-200.

---. Sons and Lovers, 1913. Ed. Helen Baron and Carl Baron. Cambridge: CUP, 1992.

---. The Ladybird, 1921. Comp. in The Fox, The Captain's Dolh, The Ladybird. Ed. Dieter Mehl. Cambridge: CUP, 1992. 157-221.

--. "Give Her a Pattern," 1929. Comp. in D. H. Lawrence: A Selection from Phoenix. Ed. A. A. H. Inglis. Harmondsworth: Penguin, 1971. 393-97.

Lerner, Laurence. "Lawrence and the Feminists." D. H. Lawrence: Centenary Essays. Ed. Mara Kalnins. Bristol: Bristol Classical Press, 1986. 69-88.

MacLeod, Sheila. Lawrence's Men and Women. London: Paladin Grafton Books, 1987.

Poe, Edgar Alan. "Ligeia," 1845. The Complete Tales and Poems. Harmondsworth: Penguin, 1987. 654-66

--.. "The Oval Portrait," 1845 The Complete Tales and Poems. Harmondsworth: Penguin, 1987. 290-2.

Shakespeare, William. Antony and Cleopatra. Ed. Emrys Jones. Harmondsworth: Penguin, 1977. Squires, Michael. "Lawrence, Dickens, and the English Novel." The Challenge of D. H. Lawrence. Ed. Michael Squires and Keith Cushman. Madison, Wis: U of Wisconsin P, 1990. 42-61.

Stannard, Unna. "The Mask of Beauty." Woman in Sexist Society: Studies in Power and Powerlessness. Ed. Vivian Gornick and Barbara K. Moran. New York and Scarborough, Ontario: The New American Library, 1971. 187-205.

Wilde, Oscar. The Picture of Dorian Gray, 1891. Comp. in The Selected Works of Oscar Wilde. London: BCA, 1991. 13-145. 